\title{
Characterization of a CDNA Clone Encoding Multiple Copies of the Neuropeptide APGWamide in the Mollusk Lymnaea stagnalis
}

\author{
A. B. Smit, ${ }^{1}$ C. R. Jiménez, ${ }^{1}$ R. W. Dirks, ${ }^{2}$ R. P. Croll, ${ }^{3}$ and W. P. M. Geraerts ${ }^{1}$ \\ 'Biological Laboratory, Vrije Universiteit, De Boelelaan 1087, $1081 \mathrm{HV}$ Amsterdam, The Netherlands, ${ }^{2}$ Department of \\ Cytochemistry and Cytometry, Leiden University, Wassenaarseweg 72, 2333 AL. Leiden, The Netherlands, and \\ ${ }^{3}$ Department of Physiology and Biophysics, Dalhousie University, Halifax, Nova Scotia, Canada B3H 4H7
}

\begin{abstract}
Male mating behavior of the simultaneous hermaphrodite freshwater snail Lymnaea stagnalis is controlled by a neuronal network that consists of various types of peptidergic neurons, as well as serotonergic cells. In the present article, we describe the isolation and characterization of a CDNA clone that encodes a multipeptide preprohormone expressed in the anterior lobe of the right cerebral ganglion, in a group of neurons that principally innervate the penial complex. The preprohormone is 219 amino acids in length and contains 10 copies of the peptide Ala-Pro-Gly-Trp-Gly. Posttranslational processing of the prohormone may lead to the generation of the amidated neuropeptide Ala-Pro-GlyTrp-amide (APGWamide), an amidated C-terminal anterior lobe peptide, and four connecting peptide sequences, C1C4. We show by in situ and filter hybridizations that neurons of the right anterior lobe comprise the major site of expression of the APGWamide gene. Expression of the APGWamide gene is detected in the CNS of both adult animals and noncopulating juveniles. Peptides derived from the APGWamide prohormone are probably involved in the control of a part of the male mating behavior and have both central and peripheral targets.
\end{abstract}

Converging evidence suggests that neuropeptides play a central role in the male sexual behaviors of many animals (e.g., Dornan and Malsbury, 1989), and the modulatory actions of peptides in the nervous system may help explain some of the unique characteristics of reproductive behaviors, such as their strong dependence upon both environmental context and internal motivational states. However, since the reproductive physiology and behaviors of many animal groups, in particular the vertebrates, are very complicated, it is often difficult to demonstrate the specific role and organization of peptidergic neurons in these processes. Some invertebrates provide simple physiological and behavioral systems that may be useful in this regard. The gastropod mollusk Lymnaea stagnalis has proven to be an advantageous model for studying the organization of the central control mechanisms of behaviors at the cellular and molecular level, primarily because the CNS consists of only a limited number of neurons, many of which are large and uniquely identifiable.

\footnotetext{
Received Aug. 9, 1991; revised Nov. 5, 1991; accepted Dec. 3, 1991.

We thank Drs. J. van Minnen and K. S. Kits for comments on the manuscript. Correspondence should be addressed to Dr. A. B. Smit, Department of Biology, Vrije Universiteit, De Boelelaan 1087, 1081 HV Amsterdam, The Netherlands. Copyright (c) 1992 Society for Neuroscience $0270-6474 / 92 / 121709-07 \$ 05.00 / 0$
}

L. stagnalis is a simultaneous hermaphrodite, in which the neuronal circuits controlling egg laying and both female and male copulation are functionally present in each individual. Thus, an individual may lay eggs and copulate as a male or as a female. The expression of these bchaviors is, however, strictly scparated in time. Several aspects of female reproductive behavior as well as the neuropeptides that control them have been well studied in this snail (Geraerts et al., 1988; Vreugdenhil et al., 1988). Also, many of the stages of male-specific behavior have been described previously (Van Duivenboden and Ter Maat 1985, 1988). A. Ter Maat, A. W. Pieneman, Y. A. Van Duivenboden, R. P. Croll, and R. F. Jansen (unpublished observations) have also furnished a description of some of the central neurons involved in the control of male reproductive behavior. That description, together with several other studies, suggested that numerous neurotransmitters may be involved in the neural control of the penial complex and vas deferens. Neurons innervating these structures include the serotonergic cells of the PeIb cluster of the right pedal ganglion (Croll and Chiasson, 1989), the FMRFamidergic neurons of the ventral lobe of the right cerebral ganglion (Schot and Boer, 1982), and possibly also some peptidergic neurons of the right pleural and parietal ganglia (Wendelaar Bonga, 1970). Another major population of penial neurons reside in the anterior lobe of the right cerebral ganglion (Khennak and McCrohan, 1988). Electron microscopical studies have revealed that these neurons contain neurosecretory granules, which suggests that they are peptidergic as well.

In the present study, we extend the earlier description of central ncurons that innervate the penial complex and the vas deferens in Lymnaea, focusing particularly on the cells of the anterior lobe of the right cerebral ganglion. In order to characterize the neuropeptide(s) produced by cells of this lobe, we sequenced a full-length cDNA clone of the most abundant mRNA present in this population. This analysis permitted the elucidation of the structure of the encoded preprohormone and the various peptides derived from it, among which the most prominent is a tetrapeptide consisting of Ala-Pro-Gly-Trp- $\mathrm{NH}_{2}$ (APGWamide). This peptide has recently been characterized in muscle tissue of the mollusk Fusinus ferrugineus by Kuroki et al. (1990). Croll et al. (1991) use immunocytochemistry and in situ hybridization to describe various populations of central neurons in Lymnaea that contain and synthesize APGWamide. They also describe physiological actions of APGWamide both on the musculature of the penis and on centrally located neurons. In combination, the body of work presented here establishes a role for APGWamide in controlling the reproductive behavior of Lymnaea, and suggests that Lymnaea may serve as a useful 
model for studying the functions of neuropeptides in complex behaviors such as those mediating male reproduction.

\section{Materials and Methods}

Animals. L. stagnalis bred in the laboratory under standard conditions (Van der Steen et al., 1969) were used. The animals were kept in continuously refreshed water, at $20^{\circ} \mathrm{C}$, on a $12 \mathrm{hr}$ light/ $12 \mathrm{hr}$ dark cycle.

Retrograde staining. The cerebral ganglia were dissected and pinned in snail saline (Geraerts et al., 1981). The cut stump of the penial nerve was then drawn tightly into the end of a finely tipped glass pipette. Saline within the pipette was replaced with a solution of $\mathrm{Ni}^{2+}-\mathrm{lysine}(1.7 \mathrm{gm}$ of $\mathrm{NiCl}_{2}-6 \mathrm{H}_{2} \mathrm{O}$ and $3.5 \mathrm{gm}$ of $\mathrm{L}-$ lysine free base in $20 \mathrm{ml} \mathrm{H}_{2} \mathrm{O}$; Fredman, 1987; S. B. Fredman, personal communication). This preparation was maintained at room temperature for $18-24 \mathrm{hr}$ before the pipette was removed, and the ganglia were washed in fresh saline. Nickel was precipitated by adding 5-10 drops of rubeanic acid (dithiooxamide; Sigma Chemical Corp., St. Louis, MO) to the $10 \mathrm{ml}$ saline bath. After 20-30 min, the ganglia were transferred to $4 \%$ paraformaldehyde in phosphate buffer for fixation overnight. Ganglia were dehydrated through an ascending alcohol series, cleared in methyl salicylate, and mounted in Malinol (from Chroma Gesellschaft, Schmid GmbH, Kongen/N, Germany). Counts of backfilled cells were obtained by direct observation.

Screening of the cDNA library. An amplified cDNA library in $\lambda \mathrm{gt} 10$ prepared from mRNA of the CNS of Lymnaea stagnalis was used (Vreugdenhil et al., 1988). mRNA was isolated (Chirgwin et al., 1979) and $\alpha$-32 P-dATP $(3000 \mathrm{Ci} / \mathrm{mmol}$, Amersham International Corp., United Kingdom) radiolabeled cDNA (specific activity, $>1 \times 10^{8} \mathrm{dpm} / \mu \mathrm{g}$ ) was prepared by oligo-(dT) ${ }_{17}$ priming and reverse transcription based upon the method of Gubler and Hoffman (1983). Twenty thousand clones were screened on Hybond- $\mathrm{N}$ membranes (Amersham International Corp.), at a density of 5000 plaque-forming units $135 \mathrm{~mm}$ filter. Plaque lifts were done as recommended by the manufacturer. The membranes were hybridized in $6 \times$ SSC $(1 \times$ SSC: $0.15 \mathrm{M} \mathrm{NaCl}$ and $0.015 \mathrm{M}$ Na-citrate), $5 \times$ Denhardt's (according to Maniatis et al., 1982), $0.1 \%$ SDS, and $10 \mu \mathrm{g}$ of salmon sperm DNA ml-1, for $16 \mathrm{hr}$ at $65^{\circ} \mathrm{C}$, washed in $1 \times \mathrm{SCC}, 0.1 \%$ SDS for $45 \mathrm{~min}$ at $65^{\circ} \mathrm{C}$, and autoradiographed.

Labeling of the APGWamide CDNA clone. A radiolabeled CDNA was synthesized by primer extension on the single-stranded M13 APGWamide cDNA clone 1 , using the Klenow fragment of DNA polymerase I. A mixture of 0.1 pmol of M13 single-stranded DNA and 0.5 pmol of primer ( $5^{\prime}$-TGACCGGCAGCAAAATG-3') was heated to $95^{\circ} \mathrm{C}$ and allowed to cool to $20^{\circ} \mathrm{C}$. Then $10 \mu \mathrm{Ci}$ of $\alpha{ }^{32} \mathrm{P}$-dATP; dGTP, dCTP, and dTTP, each at $200 \mu \mathrm{M} ; 7 \mathrm{U}$ of Klenow enzyme were added to the mixture, and the reaction was carried out for $20 \mathrm{~min}$ at $20^{\circ} \mathrm{C}$ and chased by adding $0.2 \mathrm{~mm} \mathrm{dATP}$ for $10 \mathrm{~min}$ at $20^{\circ} \mathrm{C}$. Next, free label was separated from synthesized DNA on a Sephadex G-50 column. The specific activity of the probe was $>2.5 \times 10^{8} \mathrm{dpm} / \mu \mathrm{g}$.

Size determination of preproAPGWamide $m R N A$. About $12 \mu \mathrm{g}$ of RNA from the cerebral ganglia of $L$. stagnalis were isolated (Chirgwin et al., 1979), glyoxylated, fractionated on a 1.6\% agarose gel, transferred to a Hybond-N filter, and hybridized (see above) with the radiolabeled APGWamide cDNA (see labeling APGWamide cDNA). Filters were washed in $0.5 \times \mathrm{SSC}$ for $20 \mathrm{~min}$ at $65^{\circ} \mathrm{C}$ and autoradiographed. Glyoxylated yeast (Saccharomyces carlsbergensis) ribosomal RNAs, 26 S (3400 bases) and 17S (1800 bases), were used as size markers.

Nucleotide sequence analysis. Four Eco RI fragments from the independent $\lambda$ gt 10 cDNA clones $1-4$ were subcloned in $M 13 \mathrm{mp} 19$ and sequenced in both orientations with a universal M13 primer and internal primers derived from the APGWamide cDNA sequence according to the dideoxy chain termination method (Sanger et al., 1977). Reactions were performed, using both Klenow and sequenase polymerase, with standard nucleotide mixes, and with dITP as substitute for dGTP. The Klenow fragment of DNA polymerase I was from Boehringer Mannheim (Germany), and sequenase polymerase was from United States Biochemicals Corporation (Cleveland, $\mathrm{OH}$ ).

Quantitation of $A P G W$ amide $m R N A$. About $4 \mu \mathrm{g}$ of total RNA was isolated (Chomzynski and Sacchi, 1987), glyoxylated, diluted in a volume of $200 \mu \mathrm{l}$ of $10 \mathrm{~mm} \mathrm{Na-phosphate} \mathrm{buffer,} \mathrm{pH} 7.0$, pipetted in slots, and transferred to a Hybond- $\mathrm{N}$ filter using a vacuum pump. The slots were soaked with $10 \times$ SSC, before and after addition of RNA. Filters were hybridized with the APGWamide cDNA clone $1\left(>2.5 \times 10^{8}\right.$ $\mathrm{dpm} / \mu \mathrm{g}$, see above), in $6 \times$ SSC, $5 \times$ Denhardt's, and $0.1 \%$ SDS, for 17 hr at $65^{\circ} \mathrm{C}$, and washed in $0.5 \times \mathrm{SSC}$ for $20 \mathrm{~min}$ at $65^{\circ} \mathrm{C}$. After autoradiography, the filters were stripped and rehybridized with $0.86 \mathrm{pmol}$ of 5'-TGACCGGCAGCAAAATG-3' oligonucleotide $\left(>1 \times 10^{9} \mathrm{dpm} /\right.$ $\mu \mathrm{g})$ labeled at the $5^{\prime}$ end with $\gamma^{32} \mathrm{P}-\mathrm{dATP}$, derived from the Lymnaea 18S rRNA sequence, in $6 \times \mathrm{SSC}$ for $17 \mathrm{hr}$ at $65^{\circ} \mathrm{C}$. Nonlabeled oligo was added to the hybridization mixture to obtain saturation of the probe versus the template. Filters were hybridized in $6 \times \mathrm{SSC}, 5 \times$ Denhardt's, and $0.1 \%$ SDS for $17 \mathrm{hr}$ at $65^{\circ} \mathrm{C}$; washed in $1 \times$ SSC, $0.1 \%$ SDS for 30 min at $65^{\circ} \mathrm{C}$; and autoradiographed on preflashed Kodak X-Omat. The steady state amount of $\mathrm{mRNA}$ /amount of tissue was calculated by measuring the optical density of the hybridization signals and corrected for the amount of total RNA present (as represented by the hybridization of $18 \mathrm{~S}$ rRNA). The experiments were performed in duplo. Hybridization signals were quantified using a densitometer (LKB, Sweden).

In situ hybridization. In situ hybridization was performed with an oligonucleotide probe, 5'-TTGCCCCATCCGGGCGCCCG-3', complementary to the sequence RAPGWGK, labcled with digoxigenin-dUTP [digoxigenin-dUTP and anti-digoxigenin from Boehringer Mannheim (Germany)], detected after hybridization by coupling to sheep antidigoxigenin-fluorescein isothiocyanate, and visualized by fluorescence microscopy. Labeling, hybridization, and detection conditions were performed as described by Dirks et al. (1991).

\section{Results}

\section{Backfilling axons in the penial nerve}

The penial complex is a large structure located on the right side of the body. Its sole innervation is by way of the penial nerve, which originates from the right cerebral ganglion. Nickel-lysine backfilling of the penial nerve resulted in the labeling of somata in the right parietal and pleural ganglia, in the Pelb cluster of the right pedal ganglion, and in the ventral and anterior lobes of the right cerebral ganglion. Figure 1 shows this pattern of labeling in the cerebral ganglia of one typical preparation and particularly demonstrates the asymmetry in the sizes of the left and right anterior lobes. Only the right lobe contains neurons with projections into the penial nerve. In adult snails, these neurons typically range in number from 50 to 60 and in size from 35 to $70 \mu \mathrm{m}$.

\section{The isolation and characterization of a $c D N A$ encoding the $A P G W$ amide preprohormone of the anterior lobe neurons}

Since the right anterior lobe contains many large neurons with a putative peptidergic character, we reasoned that they might form a rich source of transcripts encoding for specific neuropeptides. Therefore, we used a differential screening technique to isolate anterior lobe-specific cDNA from a $\lambda g t 10$ library of the CNS of $L$. stagnalis $\mathrm{cDNA}$ clones were obtained by screening replica filters of 20,000 clones with a positive cDNA probe, synthesized from $\mathrm{mRNA}$ isolated from the anterior lobe neurons of both cerebral ganglia. Negative screenings were performed with cDNA probes of mRNA of the dorsal bodies (female gonadotropic centers), cDNA clones encoding molluscan insulinrelated peptides (Smit et al., 1988, 1991) of the neighboring light green cells, and with cDNA made of mRNA from the digestive gland. The screening yiclded four independent, partially overlapping clones (Fig. $2 A$ ), with the longest cDNA insert 1054 base pairs (bp) (clone 1), which were subcloned as EcoRI fragments in M13mpl9.

Sequence analysis in both directions of these cDNAs revealed a single open reading frame encoding a preprohormone of 219 amino acids. cDNA clone 1 contains 97 nucleotides of the $5^{\prime}$ untranslated leader scquence and 297 nucleotides of the $3^{\prime}$ untranslated region (Fig. $2 B$ ). Initiation of translation may occur at three Met residues, at position 1, 12, or 23. Met residues at position 1 or 12 will be likely used, since translation initiation at these residues gives rise to hydrophobic signal sequences, whereas this is not the case for Met at position 23. The length 


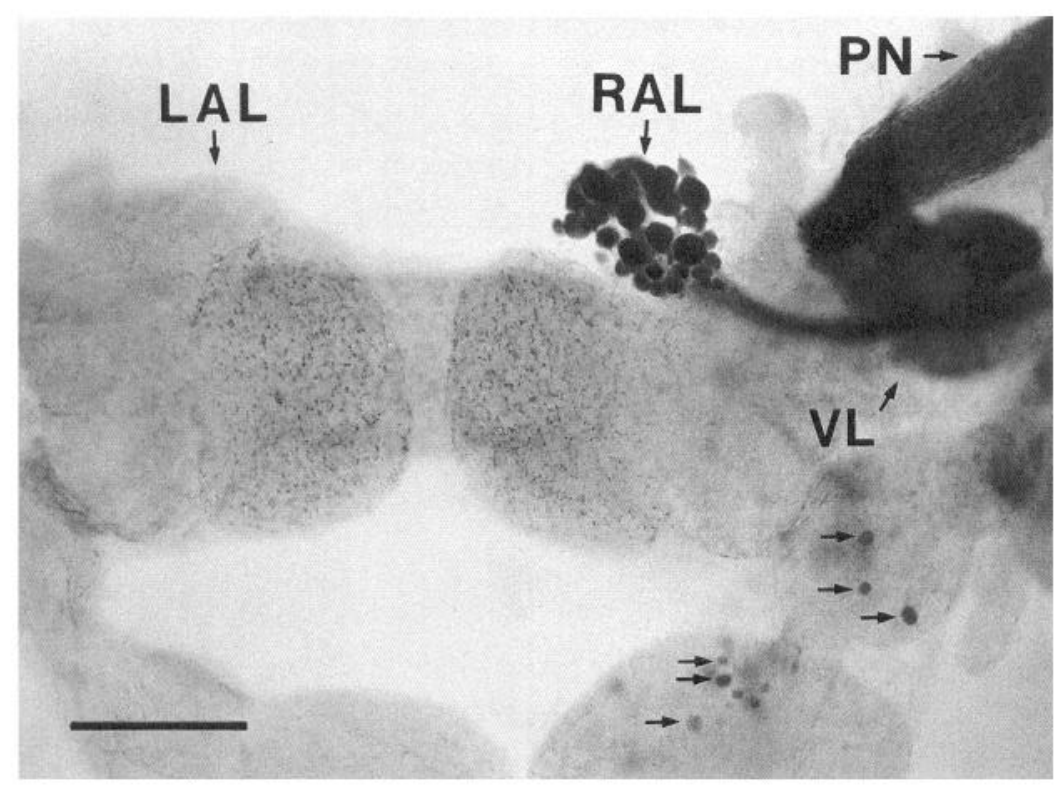

Figure 1. Central neurons stained following backfilling of the penial nerve $(P N)$ of Lymnaea. Numerous neurons are stained in the right anterior lobe $(R A L)$, whereas no neurons are stained in the smaller left anterior lobe $(L A L)$. Also visible (but out of focus on the ventral surface) are the neurons of the ventral lobe $(V L)$ of the right cerebral ganglion. Small arrows indicate some of the neurons stained on the dorsal surfaces of the right pleural and parietal ganglia. Scale bar, $400 \mu \mathrm{m}$.

of cDNA clone 1 (1054 bp), as obtained by sequence analysis, corresponds well with the length of $\sim 1100$ nucleotides of the transcript as determined by Northern blotting (Fig. 3). In addition to the Northern blot that indicates that we have cloned an almost full-length cDNA, a signal for polyadenylation may be present at position 1020 (ATTAAA).

The primary structure of the preprohormone deduced from the cDNA sequence predicts that the signal peptide has a hydrophobic character and consists of 30 residues (using Met at position 1), with Ala at position 20 as the most likely cleavage site (von Heijne, 1983). Alternatively, in the case that Met at position 12 is used for translation initiation, Ala at position 29 is the most likely cleavage site, generating a signal sequence of 18 residues. These N-terminal sequences are the most hydrophobic regions in the preprohormone. Removal of the proposed signal peptide(s) generates a prohormone with a calculated relative molecular mass of $21.8 \mathrm{kDa}$ or $20.8 \mathrm{kDa}$, respectively.

The prohormone can be endoproteolytically cleaved at 14 Lys-Arg processing sites and thereby give rise to 10 copies of the sequence Ala-Pro-Gly-Trp-Gly, a C-terminal peptide of 40 residues, called CALP (C-terminal anterior lobe peptide), and four connecting peptide domains $(\mathrm{C} 1-\mathrm{C} 4)$ (Fig. 4). The various copies of APGWG are encoded by sequences with a different codon usage. Both the APGWG peptides and CALP contain $\mathrm{C}$-terminal glycine residues, which may be posttranslationally amidated. The $\mathrm{C} 1-\mathrm{C} 4$ peptides do not contain an amidation signal. The $\mathrm{C} 1, \mathrm{C} 2$, and $\mathrm{C} 4$ domains are hydrophilic, whereas in contrast, the $\mathrm{C} 3$ domain is hydrophobic. Particularly, the $\mathrm{C} 2$ and $\mathrm{C} 4$ domain contain a high amount of charged, hydrophylic amino acids, for example, Glu (27\%) and Asp (19\%).

\section{Expression of the APGWamide gene in the CNS}

With in situ hybridization experiments on histological sections of the CNS employing an oligonucleotide directed to the APGWamide sequence, we demonstrated that the gene is indeed most prominently expressed in the neurons of the right anterior lobe (Fig. 5). In addition, gene expression was also detected in the anterior lobe of the left cerebral ganglion and in several neurons in other parts of the CNS (for further information, see Croll et al., 1991).

We quantified the amount of APGWamide-encoding mRNA in each ganglion of the CNS of adult snails and in some peripheral organs on slot blots (Fig. 6A). Expression of the gene was established in the left and right cerebral ganglia, and in the right parietal ganglion. The amount of mRNA present in the right cerebral ganglion is about threefold the amount in the left cerebral ganglion. APGWamide mRNA was detected in the right but not the left parietal ganglion. Gene expression could not be detected on the slot blots of the penial complex, the mantle, or the hepatopancreas.

The expression of the APGWamide gene was also measured by determining the steady state level of the APGWamide mRNA in the CNS, during development of the animal (Fig. $6 B$ ). Transcription of the APGWamide gene was detected already in the smallest animals used, that is, with a shell length of $5 \mathrm{~mm}$. The amount of APGWamide mRNA then increases, reaches a maximum in adult animals with a shell length of $20 \mathrm{~mm}$, and then decreases thereafter.

\section{Discussion}

In the present study, we isolated a cDNA that is abundantly expressed in the right anterior lobe of the cerebral ganglion of the snail $L$. stagnalis. Based upon the structure of the cDNA, we deduced that it may give rise to a set of neuropeptides consisting of APGWamide and CALP. Furthermore, the putative connecting domains $\mathrm{C} 1-\mathrm{C} 4$ may be derived from the precursor.

The actual presence of APGWamide in the CNS of Lymnaea has recently been confirmed by peptide purification and sequencing, and these data, in combination with mass determination, indeed indicate posttranslational amidation of both APGWamide and CALP (K. W. Li, W. P. M. Geraerts, and A. B. Smit, unpublished observations). Furthermore, Croll et al. (1991) demonstrate APGWamide-like immunoreactivity that colocalizes with an in situ signal for the expression of the gene within the CNS, and demonstrate bioactivity of the peptide both on central neurons and on muscles of Lymnaea. Together, these 


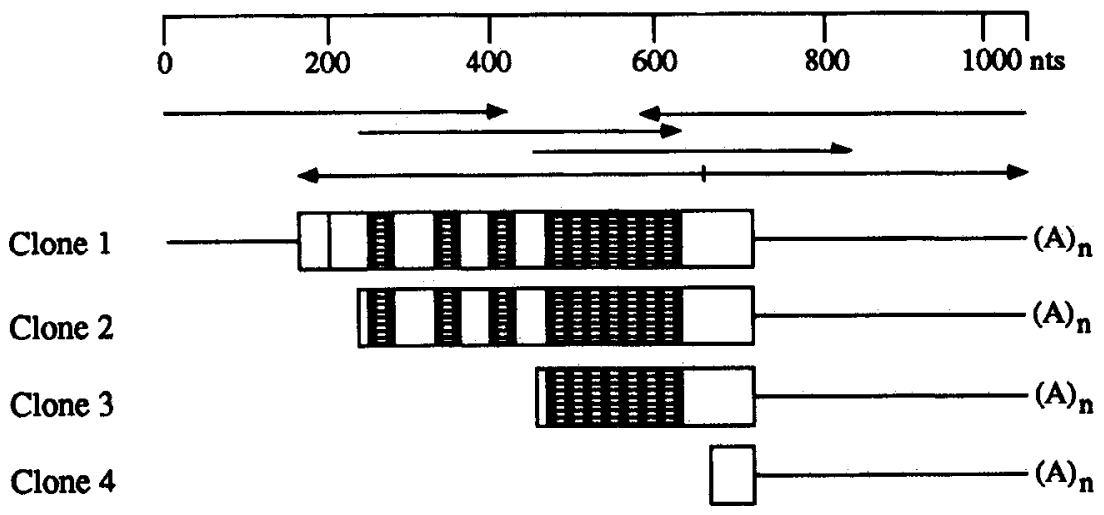

B

GTT ATC GCC TCA GTC ATG TTA TTT GAC CTC ACC GCC TCC GTG GAG TCG GCT TCG TTA TCA GGA val ile ala ser val met leu phe asp leu thr ala ser val glu ser ala ser leu ser gly 40

TCT TCC ACC GAA AAC CTA CAG ACG TCC AGC AGA CAC AAA AGA GCC CCG GGC TGG GGA AAG AGA ser ser thr glu asn leu gln thr ser ser arg his lys argala pro gly trp gly lys arg]

AAC AGT TTA AAC GAG GAG ATC CTT GAA GAG TCT GAT AAC TCG CAG GAA CTT TTG GAG AGC GTC asn ser leu asn glu glu lle leu glu glu ser asp asn ser gln glu leu leu glu ser val

GAG GAG CTG AAG CGG GCG CCG GGC TGG GGA AAG CGA TCC GGT GAG CTA GCT TTT GAC AGC GCC glu glu leu lys arg ala pro gly trp gly lys arg ser gly glu leu ala phe asp ser ala

CTG GCG GCC GAA AAG CGG GCG CCC GGA TGG GGC AAG AGA AGT GAG GAG TTC GAT CTG GAC leu ala ala glu lys arg ala pro gly trp gly lys arg ser glu glu phe asp leu asp asp GAC AGC GTG GAT CAA GAC AAG CGT GCA CCC GGA TGG GGC AAG CGG GCG CCA GGA TGG GGG AAG asp ser val asp gln asp lys arg ala pro gly trp gly lys arg ala pro gly trp gly lys CGT GCA CCC GGA TGG GGG AAA CGG GCG CCC GGA TGG GGC AAA AGA GCT CCA GGC TGG GGC AAA arg ala pro gly txp gly lys arg ala pro gly trp gly lys arg ala pro gly trp gly lys arg ala pro gly trp gly lys arg ala pxo gly trp gly lys arg ala 180

CGG GCG CCA GGA TGG GGC AAA AGA GCC CCG GGA TGG GGC AAA CGA TCG GGC AGT GAC TAC TGT arg ala pro gly txp gly lys arg ala pro gly trp gly lys arg ser gly ser asp tyr cys GAA ACA CTG AAG GAG GTT GCC GAC GAA TAT ATC TTG TTA TCC TAT AAG ATC GAA GAA CAG AGA glu thr leu lys glu val ala asp glu tyr lle leu leu ser tyr lys lle glu glu gln arg 219

GCG GCC GAC TGC GGA GGT GAA CCT CCT AAT TCC CAA GGC TGA CCCGGATGTGAACACAAGTGGGGGGAC ala ala asp cys gly gly glu pro pro asn ser gln gly stop

TCCATCCCAGGCGGACGCCATTTGAGATATTTTCATCACTACATTCTTTGCAATTCACTTCATCGGCAAGCGATTCTCAGGGC CGAAACCAGAGGACGAACGGCACTCCTTCAATAATAGATCGTGTTGTCGGCCAGCCACTCCACCAGGTCGACCAGCCACTCCA CCAGCGGTGTTCTCAAAGTGTAGTTGTGTTAGTAAGAAAATATTTCCATTTCGTGTTTCGCTTGTGAGGATTAAAGATTATGT TCACACAAAAAAATCAACTCC- pOIYA 


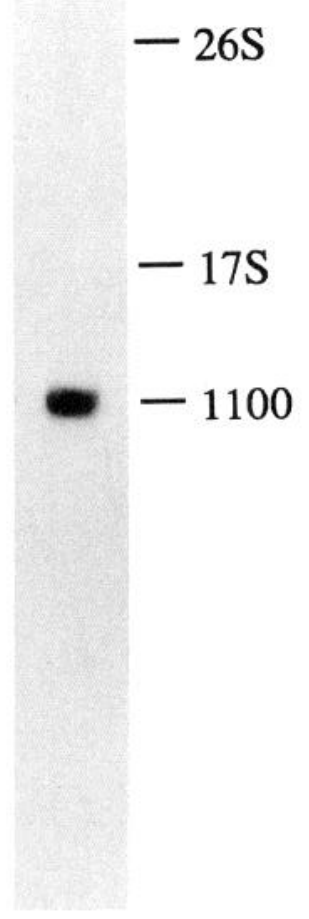

Figure 3. Size determination of preproAPGWamide mRNA as determined by Northern blotting. Total RNA $(12 \mu \mathrm{g})$ was isolated from cerebral ganglia and fractionated on a $1.6 \%$ agarose gel, blotted to $\mathrm{Hy}-$ bond-N, and hybridized to the ${ }^{32} \mathrm{P}$-labeled APGWamide cDNA clone 1. 26S (3400 bases) and $17 \mathrm{~S}(1800)$ bases indicate the positions of yeast ribosomal RNAs.

studies suggest that APGWamide is potentially an important neuropeptide in this species. Interestingly, Kuroki et al. (1990) have independently isolated APGWamide from the prosobranch mollusk, Fusinus ferrugineus. They also demonstrate that the tetrapeptide has bioactivity in other gastropod as well as bivalve preparations. More recently, J. Van Minnen (personal communication) has used immunocytochemistry to detect APGWamide in a wide range of gastropods and bivalves. Thus, it appears that APGWamide may be an important neuropeptide throughout the mollusks.

In addition to its apparently wide distribution within mollusks, APGWamide shows some similarity to the amino acid sequences of the arthropod neuropeptide $\mathrm{RPCH}$ [red pigment concentrating hormone, crustaceans (Fernlund, 1974)]. In particular, the last three residues of APGWamide are identical to those in the $\mathrm{C}$ terminus of RPCH, that is, pQLNFSPGWamide. Moreover, the residues Pro and Gly may introduce a specific C-terminus bending to both the molluscan and the arthropod peptides. APGWamide is a relatively small, hydrophobic peptide and has no particular charged side chain that could be assigned to be involved in receptor interactions. Although APGWamide and RPCH share some common structural similarities, the organization of the respective APGWamide and RPCH prohormone could be very different and may have been derived from separate but convergent evolutionary lines.

The repetition of APGWamide in the preprohormone of Lymnaea resembles the sequence repetitions found in the FMRFamide preprohormones of the gastropod mollusks Lymnaea (Linacre et al., 1990; Saunders et al., 1991) and Aplysia (Taussig and Scheller, 1986), of the fruitfly Drosophila (Schneider and Taghert, 1988), and also of the antho-RFamide prohormone of the sea anemone Calliactis parasitica (Darmer et al., 1991). APGWamide, FMRFamide, and antho-RFamide peptides are all endoproteolytically cleaved from their precursors, and the domains connecting these peptides within the prohormones, such as the $\mathrm{Cl}-\mathrm{C} 4$ connecting peptides in the APGWamide prohormone, show a high percentage of charged amino acids such as Glu and Asp. Therefore, these domains are hydrophilic and may serve to fold the various prohormones in such a way that endoproteolytic cleavage of the peptides is favored. While APGWamide is processed in the prohormone on dibasic residues (Lys-Arg) only, FMRFamide is processed on Lys-Arg residues (and very likely also on single Arg residues), whereas antho-RFamide is processed on single Arg, on Lys-Arg, and on alternative amino acids such as Glu and Asp. Probably, these cleavage events are controlled by distinct, sequence-specific endoproteolytic processing enzymes.

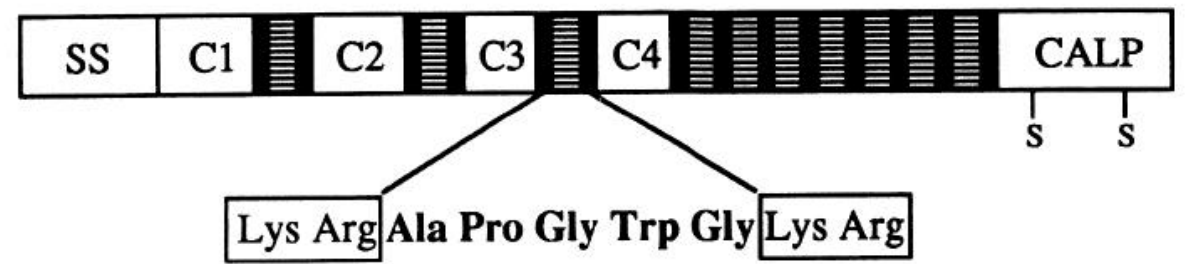

Figure 4. Schematic representation of the APGWamide preprohormone and the peptides derived from it. Indicated are $S S$, signal sequence; hatched boxes, APGWG sequences; $C 1-C 4$, connecting peptides; $C A L P, \mathrm{C}$-terminal anterior lobe peptide; solid vertical bars, Lys-Arg proteolytic processing sites; $S$, cysteine residue probably involved in the formation of a disulfide bridge(s).

\section{$\leftarrow$}

Figure 2. A, Schematic representation of the sequence strategy of four independent, overlapping preproAPGWamide cDNA clones. Clones 1,2 , 3 , and 4. Striped boxes indicate the repetitive sequence APGWG; $A_{(n)}$ indicates the presence of a polyadenylate stretch; arrows indicate the direction and extent of the sequencing runs. nts, number of nucleotides. $B$, Nucleotide sequence of the preproAPGWamide cDNA (Clone 1$)$ and its derived amino acid sequence. The number of nucleotides is indicated at the end of each line. The predicted amino acid sequence of preproAPGWamide is numbered designating the first methionine as position 1; boxes, proteolytic processing sites (Lys-Arg); in boldface, the APGWG sequence; C1$C 4$, the connecting peptide domains; $C A L P$, the sequence of the C-terminal anterior lobe peptide; vertical arrows, the predicted signal sequence cleavage sites; horizontal arrows, beginning of a peptide domain. 


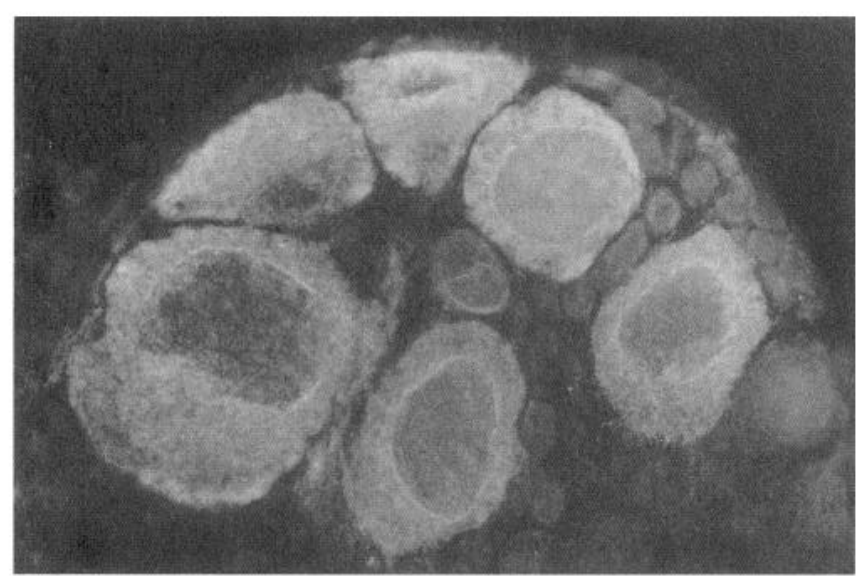

Figure 5. Localization of preproAPGWamide mRNA in large peptidergic neurons in a section of the right cerebral ganglion of $L$. stagnalis by in situ hybridization. A fluorescently labeled oligonucleotide probe derived from the APGWamide cDNA sequence was used. (The fluorescence gives the cytoplasm of the cells a white appearance.) Magnification, $200 \times$.

Amino acid sequence repetitions, like those in the APGWamide and FMRFamide prohormones, obviously favor the synthesis of large amounts of peptides from single prohormones. It is interesting to note that the amino acids of the various APGWG sequences are encoded by different codons, suggesting that putative duplications of a primordial APGWG sequence have undergone extensive base substitutions during evolution, eventually leading to the modern organization of the APGWamide prohormone.

In contrast to the information available on APGWamide, little is currently known about the peptides CALP and C1-C4, which are also encoded on the APGWamide gene expressed in the anterior lobe of Lymnaea. However, evidence for the actual synthesis of CALP in the anterior lobes has come from its isolation and subsequent sequencing $(\mathrm{K}$. W. $\mathrm{Li}$, personal communication). CALP is 40 amino acids in length and contains two cysteine residues, which may be involved in the formation of a disulfide bridge. This disulfide bridge formation may be within the monomer or, alternatively, between two monomers, giving rise to a CALP dimer. The disulfide bridge(s) may stabilize the peptide structure, thereby preventing early degradation. CALP has no sequence similarity with any other known peptide. Peptides, $\mathrm{Cl}-\mathrm{C} 4$, have not yet been detected within Lymnaea. As discussed, they probably serve as connecting peptides that are rapidly degraded after processing of the prohormone.

Several lines of evidence indicate that products of the APGWamide gene described in this article play important roles in male copulatory behavior of Lymnaea. First, RNA blot analysis demonstrates that the expression of the gene is asymmetrical between the right and left sides of the CNS, and this is consistent with the possibility that the gene is most abundantly expressed in penial neurons, which are also asymmetrically distributed within the CNS. The validity of this hypothesis is supported by the in situ hybridization experiments described in the present report and also by the results in the article of Croll et al. (1991), which describes the distribution of APGWamide-expressing neurons and their projections to male reproductive organs. Those data thus confirm and expand the results described here, based upon backfilling of the penial nerve.
A

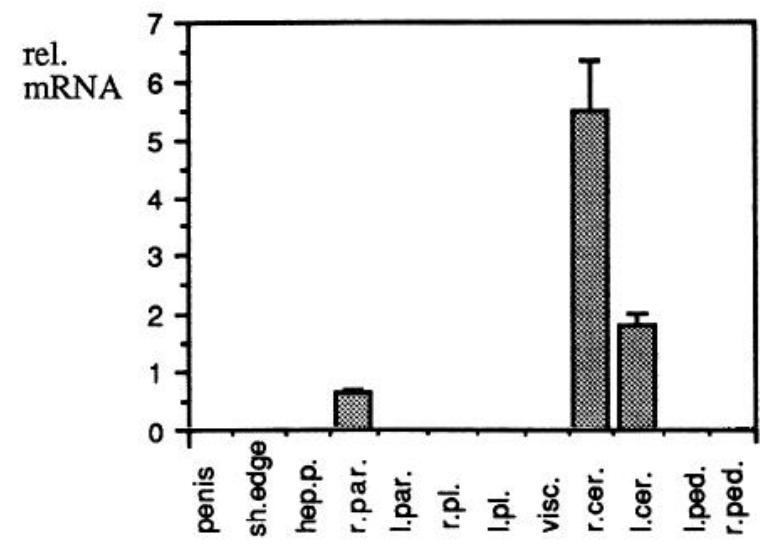

B

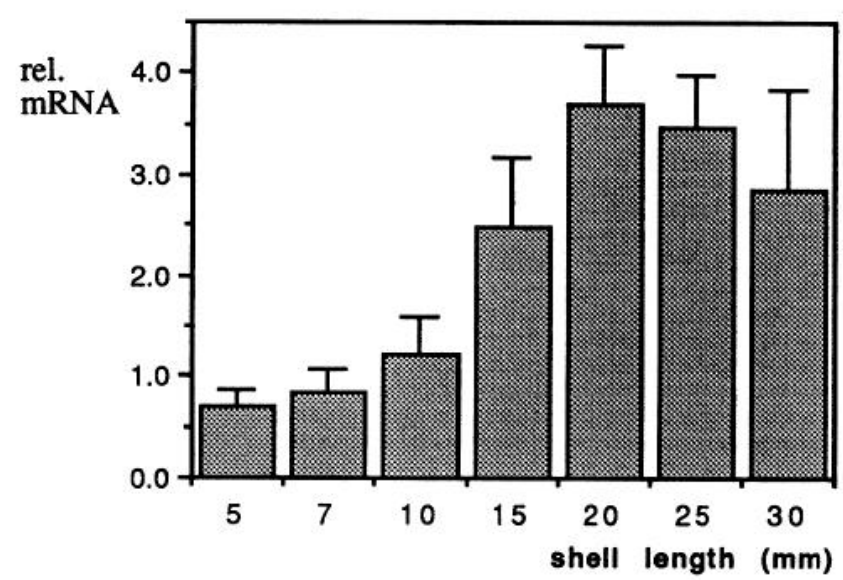

Figure 6. Gene expression in the CNS of L. stagnalis. A, Localization and quantitation of APGWamide mRNA (rel. $m R N A$, APGWamide mRNA/rRNA) in the central ganglia, the penis, the shell edge (sh.edge), and the hepatopancreas (hep.p.). Abbreviations of the ganglia: $r$. par., right parietal; l.par., left parietal; r.pl., right pleural; l.pl., left pleural; visc., visceral; r.cer, right cerebral; l.cer, left cerebral; l.ped., left pedal; r.ped., right pedal. B, Quantitation of steady state APGWamide mRNA levels in the CNS (rel. $m R N A$, APGWamide mRNA/rRNA) during development. The mean values and the standard deviations (error bars) are given.

The products of the APGWamide gene may also play a broader role than simply that of penial control. RNA blot analysis together with in situ hybridization studies (Croll et al., 1991) suggests that the gene transcript is distributed in other types of central neurons than those used for direct penial control. Also, the RNA blot analysis clearly demonstrates an early expression of the gene in animals with shell lengths of only 5-7 mm. These animals have not yet fully developed male organs and do not copulate (Van Duivenboden and Ter Maat, 1985). The onset of copulation is on a shell length of $18 \mathrm{~mm}$. Although it is not clear at present whether peptides are released at these early life stages, we favor the view that, since the gene is transcribed, its products may serve in other functions apart from male copulation. Since the expression of the gene was not quantified in the separate ganglia in this experiment, it is not certain whether transcription of the gene in these early developmental stages 
comes from neurons in the cerebral or in other ganglia. This complicated matter is currently under investigation.

The profile of gene expression during development of the snail either may reflect an increase in gene expression or, alternatively, may be due to a selective increase in the number of expressing neurons. Selective postembryonic increases in the number of central neurons, involved in male development, have also been reported for the leech (Baptista et al., 1990). The significance of the decrease in the expression of the expression of the APGWamide gene in the CNS of animals $>20 \mathrm{~mm}$ cannot be easily explained.

Whether the APGWamide neuropeptide occurs in other animal groups, for example, vertebrates, and whether it may bc involved in the control of reproductive behavior, are intriguing questions and remain to be resolved.

\section{References}

Baptista CA, Gershon TR, Macagno ER (1990) Peripheral organs control central neurogenesis in the leech. Nature 346:855-857.

Chirgwin JM, Przybyla AE, MacDonald RJ, Rutter WJ (1979) Isolation of biologically active ribonucleic acid from sources enriched in ribonuclease. Biochemistry 24:5294.

Chomzynski P, Sacchi N (1987) Single step method of RNA isolation by acid guànidinium thiocyanate phenol-chloroform extraction. Anal Biochem 162:156-159.

Croll RP, Chiasson BJ (1989) Postembryonic development of serotonin-like immunoreactivity in the central nervous system of the snail, Lymnaea stagnalis. J Comp Neurol 280:122-142.

Croll RP, Van Minnen J, Smit AB, Kits KS (1991) APGWamide: molecular, histological and physiological examination of a novel neuropeptide. In: Molluscan neurobiology (Kits KS, Boer HH, Joose J, eds), pp 248-254. Amsterdam: North-Holland.

Darmer D, Schmutzler C, Diekhof D, Grimmelikhuijzen CJP (1991) Primary structure of the sea anemone neuropeptide antho-RFamide (Glu-Gly-Arg-Phe-NH ${ }_{2}$ ). Proc Natl Acad Sci USA 88:2555-2559.

Dirks RW, van Gijlswijk RPM, Vooijs MA, Smit AB, Bogerd J, van Minnen J, Raap AK, van der Ploeg M (1991) 3'-End fluorochromized and haptenized oligonucleotides as in situ hybridization probes for multiple, simultaneous RNA detection. Exp Cell Res 194:310315.

Dornan WA, Malsbury CW (1989) Neuropeptides and male sexual behavior. Neurosci Biobehav Rev 13:1-15.

Fernlund $P$ (1974) Structure of the red pigment concentrating hormone of the shrimp, Pandalus borealis. Biochem Biophys Acta 371:304 311.

Fredman SB (1987) Intracellular staining of neurons with nickel lysine. J Neurosci Methods 20:181-194.

Geraerts WPM, Van Leeuwen JPTM, Nuyt K, de With ND (1981) Cardioactive peptides of the CNS of the pulmonate snail, Lymnaea stagnalis. Experientia 37:1168-1169.

Geraerts WPM, Ter Maat A, Vreugdenhil E (1988) The peptidergic neuroendocrine control of egg laying behaviour in Aplysia and Lymnaea. In: Invertebrate endocrinology, $\mathrm{Vol} 2$, Endocrinology of selected invertebrate types (Laufer H, Downer R, eds), pp 144-231. New York: Liss.
Gubler H, Hoffman BJ (1983) A simple and very efficient method for oenerating cDNA libraries. Gene 25:263-269.

Khennak M, McCrohan CR (1988) Cellular organization of the cerebral anterior lobes in the central nervous system of Lymnaea stagnalis. Comp Biochem Physiol [A] 91:387-398.

Kuroki Y, Kanda T, Kubota I, Fujisawa Y, Ikeda T, Miura A, Minamitake Y, Muneoka YA (1990) Molluscan neuropeptide related to the crustacean hormone, RPCH. Biochem Biophys Res Commun 167: 273-279.

Linacre A, Kellet E, Saunders S, Bright K, Benjamin PR, Burke JF (1990) Cardioactive neuropeptide Phe-Met-Arg-Phe-NH (FMRFamide) and novel related peptides are encoded in multiple copies by a single gene in the snail, Lymnaea stagnalis. J Ncurosci $10: 412-419$

Maniatis T, Fritsch EG, Sambrook J (1982) Molecular cloning. Cold Spring Harbor, NY: Cold Spring Harbor Laboratory.

Sanger F, Nicklen S, Coulson AR (1977) DNA sequencing with chain terminating inhibitors. Proc Natl Acad Sci USA 74:5463-5467.

Saunders SE, Bright K, Kellet E, Benjamin PR, Burke JF (1991) Neuropeptides Gly-Asp-Pro-Phe-Leu-Arg-Phe-amide(GDPFLRFamide) and Ser-Asp-Pro-Phe-Leu-Arg-Phe-amide (SDPFLRFamide) are encoded by an exon 3' to Phe-Met-Arg-Phe-amide (FMRFamide) in the snail, Lymnaea stagnalis. J Neurosci 11:740-745.

Schneider LE, Taghert PH (1988) Isolation and characterization of a Drosophila gene that encodes multiple neuropeptides related to Phe-

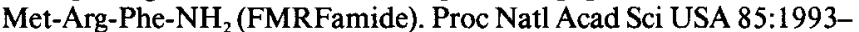
1997.

Schot LPC, Boer HH (1982) Immunocytochemical demonstration of peptidergic cells in the pond snail, Lymnaea stagnalis, with an antiserum to the molluscan cardioactive peptide, FMRFamide. Cell Tissue Res 225:347-354.

Smit AB, Vreugdenhil E, Ebberink RHM, Geraerts WPM, Klootwijk J, Joosse J (1988) Growth-controling molluscan neurons produce the precursor of an insulin-related peptide. Nature 331:535-538.

Smit AB, Geraerts WPM, Meester I, Van Heerikhuizen H, Joosse J (1991) Characterization of a cDNA clone encoding molluscan insulin-related peptide II. Eur J Biochem 199:699-703.

Taussig R, Scheller RH (1986) The Aplysia FMRFamide gene encodes sequences related to mammalian brain peptides. DNA 5:453-461.

Van der Steen WJ, van den Hoven NP, Jager JC (1969) A method for breeding and studying freshwater snails under continuous water change, with some remarks on growth and reproduction in Lymnaea stagnalis. Neth J Zool 19:131-139.

Van Duivenboden YA, 'Ter Maat A (1985) Masculinity and receptivity in the hermaphrodite pond snail, Lymnaea stagnalis. Anim Behav 33:885-891.

Van Duivenboden YA, Ter Maat A (1988) Mating behaviour of Lymnaea stagnalis. Malacologia 28:53-64.

von Heijne $G$ (1983) A new method for predicting signal sequence cleavage sites. Nucleic Acids Res 14:4683-4690.

Vreugdenhil E, Jackson JF, Bouwmeester T, Smit AB, Van Minnen J, Van Heerikhuizen H, Klootwijk J, Joosse J (1988) Isolation, characterization, and evolutionary aspects of a cDNA clone encoding multiple neuropeptides involved in the stereotyped egg-laying behavior of the freshwater snail, Lymnaea stagnalis. J Neurosci 8:41844191.

Wendelaar Bonga SE (1970) Ultrastructure and histochemistry of neurosecretory cells and neuroheamal areas in the pond snail Lymnaea stagnalis. Z Zellforsch 108:190-224. 